The aim of the study: To analyze human breast cancer cell line MCF-7 and human malignant melanoma cell line WM-115 in order to characterize the cellular expression of CP and to evaluate whether ATO may affect this activity, as well as the viability of the cells. Material and methods: The inhibitory effect of arsenic trioxide on the proliferation of MCF-7 and WM-115 cells were measured with MTT test. The activity of cancer procoagulant after ATO exposure was determined by a specific three-stage chromogenic assay. Results: ATO decreased the CP activity in a dose- and time-dependent manner in MCF-7 cells with no effect on cell proliferation at the same time. However, it affected the CP activity of WM-115 cells in a different way. Reduction in CP activity was followed by an increase after $48 \mathrm{~h}$ incubation. The cells viability results showed doseand time-correlated response within high arsenic concentrations.

Conclusions: Arsenic trioxide downregulates the $\mathrm{CP}$ expression in human breast cancer and melanoma cells.

Key words: arsenic trioxide, cancer procoagulant, breast cancer, melanoma.

Contemp Oncol (Pozn) 2015; 19 (2): 108-112 DOI: $10.5114 /$ wo.2014.41390

\section{Arsenic trioxide downregulates cancer procoagulant activity in MCF-7 and WM-115 cell lines in vitro}

\author{
Ewelina A. Hoffman, Katarzyna Gizelska, Marek Mirowski, Wojciech Mielicki
}

Department of Pharmaceutical Biochemistry and Molecular Diagnostics, Medical University of Lodz, Lodz, Poland

\section{Introduction}

Blood coagulation plays an important role in the occurrence of cancer. Activation of the coagulation system in malignancy enables tumor spreading and thus it is associated with poor prognosis [1-3]. Tumor cells are able to initiate blood clotting cascade due to expression of various procoagulants and inflammatory cytokines, and the interaction between tumor cells and blood (i.e. monocytes/macrophages, platelets) and endothelial cells [4]. Two major procoagulants from malignant tissues are tissue factor (TF) and cancer procoagulant (CP) [2].

Tissue factor (TF) is a transmembrane glycoprotein expressed by normal and malignant tissues [3]. Cancer procoagulant belongs to cysteine proteinase superfamily and is described in malignant and fetal, but not in normally differentiated tissues $[1,3,5]$. The mechanisms of interactions between malignant cell and CP are still not well established. It is accepted that CP has proadhesive properties together with factor $X$-activating activity [6]. Experimental data suggest that CP plays an important role in tumor growth and metastasis [1].

Arsenic trioxide has been confirmed to be an effective cure for relapsed acute promyelocytic leukemia (APL) patients [7]. Acute promyelocytic leukemia is characterized by a special clinical picture with severe bleeding diathesis. The coagulopathy of patients with APL has been a challenge for clinical hematology, especially during cytotoxic chemotherapy. Excessive procoagulant activity in APL is related to generation of factor Xa via expressed TF as well as CP [8, 9]. Since 1988 all-trans retinoic acid (ATRA) has been introduced for treatment of APL with beneficial effects [10-12]. Recently, arsenic trioxide has also been used clinically as an effective therapeutic agent in relapsed ATRA-resistant patients. It is worth emphasizing that both ATRA and ATO induced remission of the bleeding symptoms [13]. The effectiveness of arsenic in the therapy of leukemia was the basis for further studies and its application in treatment of solid tumors. It has been evidenced that ATO induces apoptosis via alteration of cell cycle phases, activating apoptotic caspases in MCF-7 cell model [14]. However, there is no studies describing the impact of ATO on cellular procoagulant activity in solid tumor cell.

Breast cancer is associated with an increased risk of thrombosis particularly during chemotherapy and hormone-therapy [15]. Chemotherapy could be accompanied by venous thromboembolism, observed in about $18 \%$ of advanced breast cancer patients [16, 17]. We chose breast cancer cell line, because several studies reported significant changes in coagulation markers in response to chemotherapy [16].

Melanoma-associated DIC (disseminated intravascular coagulation) has rarely been reported. However, there have been reports concerning other coagulation disorders associated with melanoma such as micro-angiopathic haemolytic anemia and subacute primitive fibrinolysis [18, 19]. A study of coagulation and fibrinolysis parameters of patients suffering from malignant melanoma compared with controls evidenced increased rates of coag- 
ulation parameters [18]. TF could play an important role in evolution of DIC in melanoma. However, human malignant melanoma cell line WM-115 is described as highly aggressive and a low-TF producer [20]. It was chosen for the present studies because WM-115 cells produce CP that may potentially play the role in generating bleeding disorders in melanoma patients.

In this study we analyze human breast cancer cell line MCF-7 and human malignant melanoma cell line WM-115 in order to characterize the cellular expression of CP and evaluate whether ATO may affect this activity, as well as the viability of the cells after arsenic trioxide treatment.

\section{Material and methods}

\section{Arsenic trioxide}

Arsenic trioxide (Sigma, USA) was dissolved in phosphate buffered saline (PBS) (Gibco, UK) at a concentration of $1 \mathrm{mM}$ as a stock solution and diluted to a working solution before use. In accordance with the range of ATO peak serum concentrations in blood of patients with APL, similar concentrations of ATO $(0.1,0.5,1,1.5,2,5$ and $10 \mu \mathrm{M})$ were tested.

\section{Cell culture}

Human breast cancer cell line MCF-7 and human malignant melanoma cell line WM-115 were cultured at $37^{\circ} \mathrm{C}$ in a $5 \% \mathrm{CO}_{2} / 95 \%$ air atmosphere. MCF-7 cell line is estrogen-receptor positive (ER+) and it is characterized as low metastatic in vivo [21]. WM-115 cell line is described as highly aggressive and metastatic, and a low TF-producer [20]. Culture media consisted of Dulbecco's Modified Eagle Medium (DMEM) (Gibco, UK), supplemented with gentamycin $(20 \mu \mathrm{g} / \mathrm{ml})$ (Polfa, Poland) and 10\% fetal calf serum (Gibco, UK) inactivated at $56^{\circ} \mathrm{C}$ for $30 \mathrm{~min}$. The cells were cultured in $75 \mathrm{~cm}^{2}$ flask (Nunc, Denmark) and confluent monolayer was trypsynized using $0.25 \%$ trypsin (Biomed, Poland) containing 5.3 mM EDTA (POCH, Poland). Cell viability was evaluated with trypan blue exclusion dye (Sigma, USA) and was always above 98\%.

\section{Cancer procoagulant activity assay}

For CP activity assays, cells were placed into 24-well plates (Nunc, Denmark) (MCF-7: $1000 \mu$ l of cell suspension containing 20000 cells/well; WM-115: $1000 \mu$ l cell suspension containing 10000 cells/well) and cultured for $24 \mathrm{~h}$ (WM-115) or $48 \mathrm{~h}$ (MCF-7) to allow for cell attachment. Then the cells were treated with serum free medium in absence (control cells were treated with the vehicle of $\mathrm{As}_{2} \mathrm{O}_{3}$ ) or presence of $\mathrm{As}_{2} \mathrm{O}_{3}(0.1,0.5,1,1.5,2,5$ and $10 \mu \mathrm{M})$. After incubation for 24, 48, 72, 96, 120 hours monolayer of MCF-7 cell in the 24-well plate (Nunc, Denmark) was briefly washed with PBS buffer (Gibco, UK) then 20 mM Tris (Sigma, USA) buffer pH 7.8 was added $(1 \mathrm{ml} /$ well) and the plate was placed at $+4^{\circ} \mathrm{C}$ for overnight to obtain the cells extracts.

$\mathrm{CP}$ activity was determined in the cell lysates by a specific three-stage chromogenic assay modified to microplate format [22]. Briefly, $50 \mu$ of TRIS cell extract was mixed with $5 \mu \mathrm{l}$ of human factor $X(100 \mu \mathrm{g} / \mathrm{ml})$ and $15 \mu \mathrm{l}$ of $25 \mathrm{mM} \mathrm{CaCl}_{2}$ (Sigma, USA) in $50 \mathrm{mM}$ bis-Tris propane
(Sigma, USA) buffer ( $\mathrm{pH}$ 6.7). After 30 minutes of incubation at $37^{\circ} \mathrm{C}, 5 \mu \mathrm{l}$ of human prothrombin $(1 \mathrm{mg} / \mathrm{ml})$ and $15 \mu$ of rabbit brain cephalin $(\mathrm{RBC}) / \mathrm{Ca}^{2+}$ mix were added to the samples $\left[(\mathrm{RBC}) / \mathrm{Ca}^{2+}\right.$ mix $=1$ part of a $\mathrm{RBC} 10 \times$ diluted with water +1 part of $50 \mathrm{mM} \mathrm{CaCl}_{2}+2$ parts of $100 \mathrm{mM}$ bis-Tris propane buffer ( $\mathrm{pH}$ 7.8)]. After further 30 minutes of incubation at $37^{\circ} \mathrm{C}$, the thrombin substrate SarPro-Arg-p-nitroanilide (2 mM in 10\% DMSO) (Sigma, USA) was added. Color development at $405 \mathrm{~nm}$ was recorded in time. Samples CP content was expressed as $\mathrm{mU} / \mathrm{ml}(1 \mathrm{U}=$ the amount of enzyme responsible for releasing $1 \mu \mathrm{mol}$ of p-nitroanilide from the substrate in 1 minute).

\section{MTT cell proliferation test}

The test was performed to assess cell viability after treatment with increasing concentrations of arsenic trioxide. The MTT test is based on reduction of tetrazolium salt by mitochondrial enzymes, which is possible only in live cells. Therefore, 3-[4,5-dimethylthiazol-2-yl]-2,5 diphenyltetrazolium bromide (MTT) (Sigma, USA) was dissolved in sterile phosphate-buffered saline (Gibco, UK) (PBS solution $5 \mathrm{mg} / \mathrm{ml}$ ) and added to cell cultures according to the method already described [23]. For proliferation assays, cells were placed into 96-well plates (Nunc, Denmark) (MCF-7: $100 \mu \mathrm{l}$ of cell suspension containing 5000 cells/well; WM-115: $100 \mu \mathrm{l}$ cell suspension containing 1000 cells/well) and cultured for $24 \mathrm{~h}$ (WM-115) or $48 \mathrm{~h}$ (MCF-7) to allow for cell attachment. Then cells were treated with serum free medium in absence (control cells were treated with the vehicle of $\left.\mathrm{As}_{2} \mathrm{O}_{3}\right)$ or presence of $\mathrm{As}_{2} \mathrm{O}_{3}(0.1,0.5,1,1.5,2,5$ and $10 \mu \mathrm{M})$. After 24, 48, 72, 96, 120 hours of incubation, $10 \mu \mathrm{l}$ of MTT was added to each well and incubated for another 2 hours. Then $100 \mu$ l of stop mix solution [20\% SDS (Sigma, USA) in 50\% dimethyl formamide (Sigma, USA)] was added to each well and incubated overnight to dissolve the darkblue formazan crystals formed. Finally, the absorbance was measured with a spectrophotometer at $570 \mathrm{~nm}$. All the tests were carried out in triplicate and compared with control wells in which no arsenic trioxide was added. Cell survival rate was calculated with the following equation: average absorbance value of experimental group/average absorbance value of control group $\times 100 \%$.

\section{Results}

\section{Cancer procoagulant activity}

The cells were exposed to $0.1,0.5,1,1.5,2,5$ or $10 \mu \mathrm{M}$ ATO for 24, 48, 72, 96 or $120 \mathrm{~h}$. For both cell lines CP activity was expressed as the percentage of CP control activity (Fig. 1). Cancer procoagulant activity in MCF-7 control cells group was between 2600-6800 mU/mg and in WM-115 control cells group between 1600-6900 mU/mg (Table 1).

\section{MCF-7 cell line}

The time- and dose-dependent effect of ATO on CP activity was observed over the ATO concentration and over the entire incubation period. After $24 \mathrm{~h}$ of incubation with $5 \mu \mathrm{M}$ and $10 \mu \mathrm{M}$ ATO CP activity was reduced to $64 \%$ and $58 \%$ of control respectively and the activity was barely 

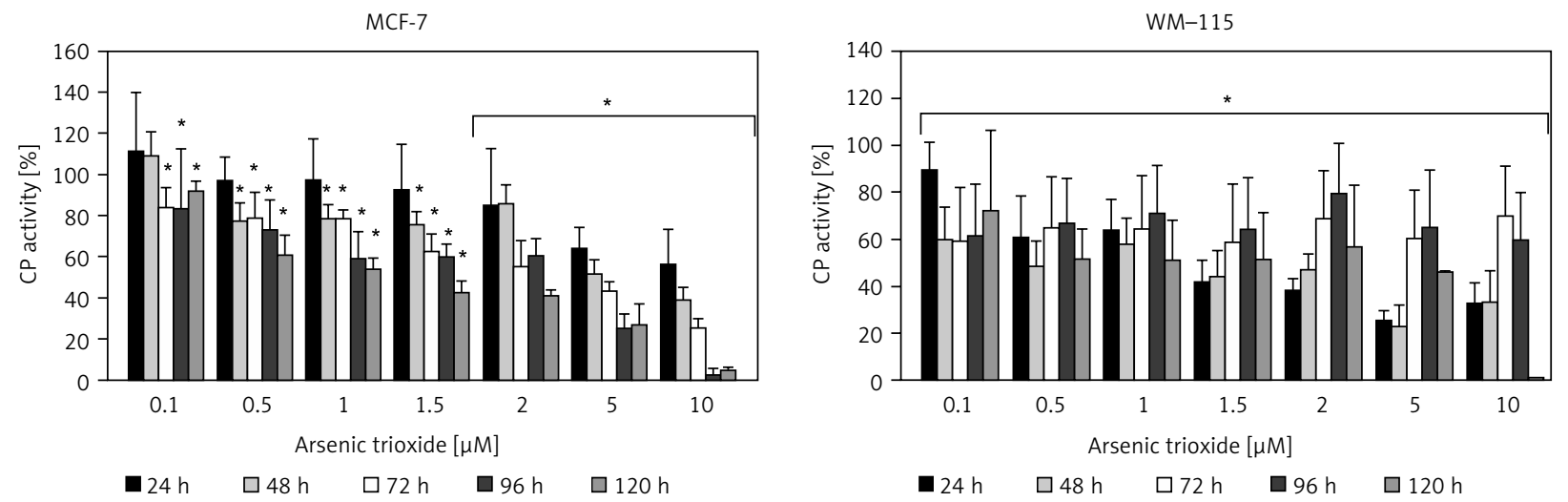

Fig. 1. Cancer procoagulant activity in cultured MCF-7 and WM-115 cells after exposition to arsenic trioxide

Data are expressed as a percentage of cancer procoagulant (CP) activity with respect to untreated control. The results are expressed as the mean of three different experiments, $\pm S D .{ }^{*}$ the differences were statistically significant, the $p$ values were $<0.01$

Table 1. Cancer procoagulant activity $(\mathrm{mU} / \mathrm{mg})$

\begin{tabular}{ccc} 
& MCF-7 & WM-115 \\
\hline $24 \mathrm{~h}$ & $2697 \pm 899$ & $2920 \pm 343$ \\
\hline $48 \mathrm{~h}$ & $3891 \pm 387$ & $1587 \pm 293$ \\
$72 \mathrm{~h}$ & $6887 \pm 926$ & $3150 \pm 894$ \\
$96 \mathrm{~h}$ & $5539 \pm 700$ & $3040 \pm 559$ \\
$120 \mathrm{~h}$ & $6783 \pm 879$ & $6990 \pm 990$
\end{tabular}

Cancer procoagulant activity in cultured MCF-7 and WM-115 control cells (untreated cells). The results are expressed as the mean of at least three different experiments, $\pm S D$.

detectable after $120 \mathrm{~h}$ of incubation. For lower concentrations of ATO a significant decrease in CP activity was also observed and it was $60 \%$ after $120 \mathrm{~h}$ of incubation for 0.5 $\mu \mathrm{M}$ concentration of ATO.

\section{WM-115 cell line}

The CP activity was decreased to $89 \%$ after $24 \mathrm{~h}$ incubation with the lowest $0.1 \mu \mathrm{M}$ arsenic trioxide dose. Higher doses: $0.5-10 \mu \mathrm{M}$ caused inhibition in CP activity below $80 \%$ within $48 \mathrm{~h}$ incubation compared with untreated control. This reduction was followed by increase after 48 hours. However, the loss of CP activity after $120 \mathrm{~h}$ incubation for $10 \mu \mathrm{M}$

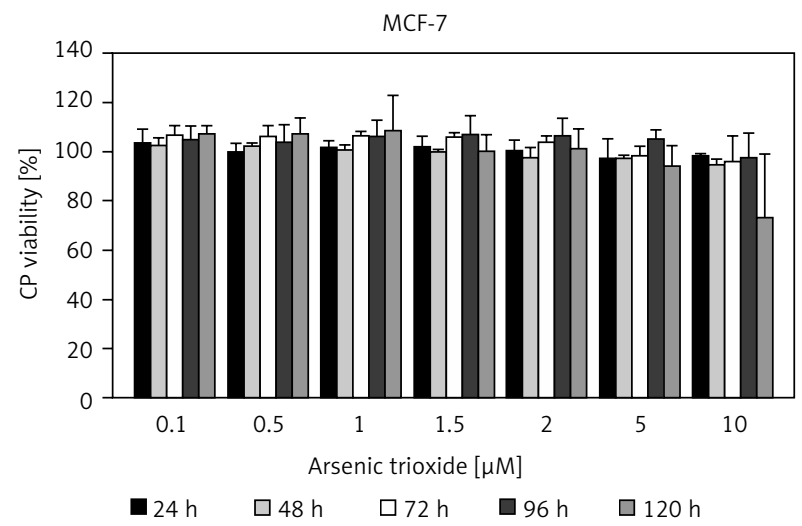

concentration of arsenic was also observed. All data were considered statistically significant ( $p$ values were $<0.01$ ).

\section{Cell proliferation}

MTT assay results were expressed as the percentage of the control cell viability (Fig. 2).

\section{MCF-7 cell line}

The MTT test demonstrated that ATO did not affect cell proliferation. For most time periods and ATO concentrations the cell viability was performed around $100 \%$ of control. The inhibition of the cell proliferation to $74 \%$ was observed only after $120 \mathrm{~h}$ incubation with $10 \mu \mathrm{M}$ ATO.

\section{WM-115 cell line}

The response showed no change in cell viability within dose range between 0.1-1.5 $\mu \mathrm{M}$, followed by a gradual decline. Application of $5 \mu \mathrm{M}$ and $10 \mu \mathrm{M}$ ATO resulted in reduction to $37 \%$ and $0 \%$ of cell viability respectively within $120 \mathrm{~h}$ incubation compared with control.

\section{Discussion}

The aim of present work was to evaluate the arsenic trioxide influence on the CP activity in MCF-7 and WM-115 cell line in vitro. In this study we demonstrate for the first

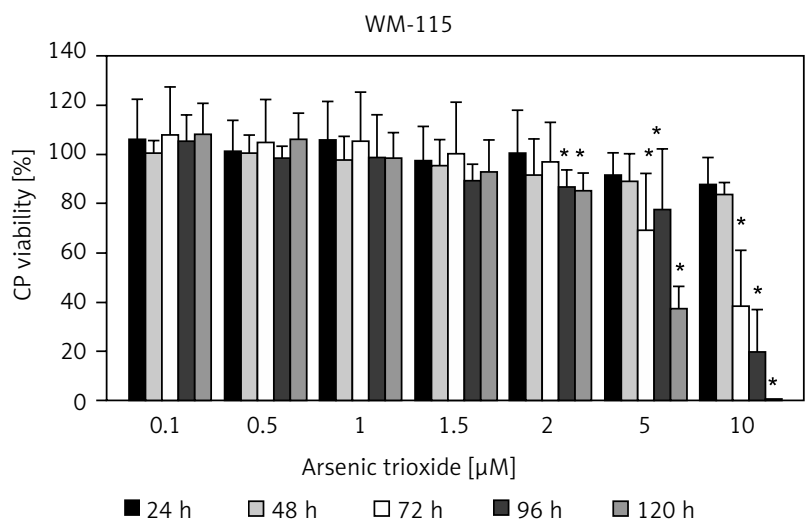

Fig. 2. Cytostatic effect of arsenic trioxide on cultured MCF-7 and WM-115 cells 
time that ATO can reduce CP activity of breast and melanoma cancer cells. The effect is getting stronger together with the increase of ATO dose.

Cancer procoagulant directly activates blood coagulation factor $X$ in absence of activated factor VII. Cancer procoagulant is described in malignant and fetal tissues, but its genomic sequence is unknown $[10,24]$. Cancer procoagulant activity reduction as a result of the application of different cytostatics e.g. all-trans retinoic acid (ATRA), was previously described [10, 13, 25]. Marchetti et al. [10] demonstrated that ATRA downregulates the expression of TF and CP in breast cancer cells. In our study it was shown for the first time that also arsenic trioxide induces reduction in CP activity. The mechanism of ATO action is still unclear, but obviously it is different in breast and melanoma cancer cells. It is probably associated with different characterization of these two cancer types. Firstly, MCF-7 cells are non-aggressive while WM-115 cells are described as highly malignant. Secondly, MCF-7 cells are estrogen-dependent in contrast to WM-115, which do not depend on hormones for growth [21]. MCF-7 cells express estrogen and progesterone receptors [26]. Finally, there is a difference in TF and CP expression. MCF-7 cells express both proteins while WM-115 cells are known as a very low TF-producer [20]. The WM-115 lysates contain no TF and enzymatic characteristics of the procoagulant activity was typical for CP [24].

Similarity in therapeutic effect of ATO and ATRA in leukemic cells suggests a similarity in their mechanism of action. According to Marchetti et al. [10], ATRA affected $\mathrm{CP}$ expression in estrogen receptor positive and negative breast cell lines. Falanga et al. [27] presented that ATRA-induced modulation of CP occurs in parallel with signs of cell differentiation [27]. Moreover, it has been evidenced that CP activity loss is correlated with remission of cancer $[28,29]$. We observed reduction in CP expression in MCF-7 cells in dose and time-dependent manner, but ATO did not inhibit cell proliferation. The cells grew with similar velocity to a control group. Any variation in cell proliferation had not been found statistically significant. It seems that MCF-7 cells are resistant to apoptotic effect of ATO. It may be due to lack of caspase-3 expression which is crucial for apoptosis induction [30-32]. On the other hand, in APL cells, the downregulation of CP by ATRA is associated with cell differentiation and cancer remission [27]. More studies need to be performed to check cell morphology after arsenic trioxide treatment and verify if cells proliferation is correlated with cell differentiation to normal cells.

The results obtained from melanoma cells investigation indicated on decreasing CP activity followed by a gradual increase. The loss of CP activity was observed after $24 \mathrm{~h}$ incubation with the whole range of ATO concentration. The higher concentration of ATO, the higher reduction in CP activity compared to control. The loss in CP activity was maintained within next two days of incubation. However, longer incubation time resulted in new rising of CP activity. It seems that melanoma cells are sensitive to ATO at the beginning of treatment. Probably, some of the cells meet apoptosis and those, which are still vivid, became resistant in longer course. The results from MTT showed that antiproliferative effect of ATO on WM-115 is dose- and time-correlated within 2-5 $\mathrm{MM}$ concentration range. It was also observed slightly increase in cell viability below $2 \mu \mathrm{M}$ concentration, however there is no statistically significant difference. These results are in agreement with previous studies separately performed in diverse cell types, which have contributed to explain the carcinogenic properties of arsenic [33-35]. The increasing CP activity was possibly due to feedback regulation of CP. More researches should be done to verify this thesis.

All in all, we demonstrate arsenic impact on CP activity in breast and melanoma cancer cells. Since coagulation activation plays a pivotal role in tumor progression, further studies should check if the capacity of ATO to decrease CP correlate with total procoagulant activity. Obtained results may open new perspectives in tumor therapy.

In conclusion, this study demonstrates for the first time that arsenic trioxide downegulates the CP activity in breast and melanoma cancer cells and could reduce the viability of melanoma cells. Results of present work may be significant for understanding the nature of some cancer associated hypercoagulation.

\section{The authors declare no conflict of interest.}

\section{References}

1. Falanga A, Marchetti M, Vignoli A, Balducci D. Clotting mechanisms and cancer: implications in thrombus formation and tumor progression. Clin Adv Hematol Oncol 2003; 1: 673-8.

2. De Cicco M. The prothrombotic state in cancer: pathogenic mechanisms. Crit Rev Oncol Hematol 2004; 50: 187-96.

3. Sampson MT, Kakkar AK. Coagulation proteases and human cancer. Biochem Soc Trans 2002; 30: 201-7.

4. Kerk N, Strozyk EA, Poppelmann B, Schneider SW. The mechanism of melanoma-associated thrombin activity and von Willebrand factor release from endothelial cells. I Invest Dermatol 2010; 130: 2259-68.

5. Falanga A. Tumor cell prothrombotic properties. Haemostasis 2001; 31 Suppl 1: 1-4

6. Olas B, Wachowicz B, Mielicki WP. Role of phosphoinositide 3-kinase in adhesion of platelets to fibrinogen stimulated by cancer procoagulant. Platelets 2001; 12: 431-5.

7. Zhang TD, Chen GQ, Wang ZG, Wang ZY, Chen SJ, Chen Z. Arsenic trioxide, a therapeutic agent for APL. Oncogene 2001; 20: 7146-53.

8. Zhou J, Shi J, Hou J, Cao F, Zhang Y, Rasmussen JT, Heegaard CW, Gilbert GE. Phosphatidylserine exposure and procoagulant activity in acute promyelocytic leukemia. J Thromb Haemost 2010; 8: 773-82.

9. Falanga A, Rickles FR. Pathogenesis and management of the bleeding diathesis in acute promyelocytic leukaemia. Best Pract Res Clin Haematol 2003; 16: 463-82.

10. Marchetti M, Russo L, Balducci D, Falanga A. All trans-retinoic acid modulates the procoagulant activity of human breast cancer cells. Thromb Res 2011; 128: 368-74.

11. Zhao W, Wang X, Guo W, Qu B, Wang H, Shen Z, Chen Z, Wang Z. Hemostatic abnormalities associated with acute promyelocytic leukemia and corrective effects of all-trans-retinoic acid or arsenic trioxide treatment. Chin Med J (Engl) 2000; 113: 236-40.

12. Koyama T, Hirosawa S, Kawamata N, Tohda S, Aoki N. All-trans retinoic acid upregulates thrombomodulin and downregulates tissue-factor expression in acute promyelocytic leukemia cells: distinct expression of thrombomodulin and tissue factor in human leukemic cells. Blood 1994; 84: 3001-9.

13. Zhao W, Wang H, Wang X, Wu F, Guo W, Qu B, Shen Z, Wang Z. Effects of all-trans-retinoic acid and arsenic trioxide on the hemo- 
static disturbance associated with acute promyelocytic leukemia. Thromb Res 2001; 102: 197-204.

14. Ruiz-Ramos R, Lopez-Carrillo L, Rios-Perez AD, De Vizcaya-Ruíz A, Cebrian ME. Sodium arsenite induces ROS generation, DNA oxidative damage, HO-1 and c-Myc proteins, NF-kappaB activation and cell proliferation in human breast cancer MCF-7 cells. Mutat Res 2009; 674: 109-15.

15. Medioni J, Guastalla JP, Drouet L. Thrombosis and breast cancer: incidence, risk factors, physiopathology and treatment. Bull Cancer 2012; 99: 199-210.

16. Kirwan CC, McDowell G, McCollum CN et al. Early changes in the haemostatic and procoagulant systems after chemotherapy for breast cancer. Br J Cancer 2008; 99: 1000-6.

17. Onitilo AA, Doi SA, Engel JM, Glurich I, Johnson J, Berg R. Clustering of venous thrombosis events at the start of tamoxifen therapy in breast cancer: A population-based experience. Thromb Res 2011; 130: 27-31.

18. Langer F, Spath B, Haubold K, et al. Tissue factor procoagulant ac tivity of plasma microparticles in patients with cancer-associated disseminated intravascular coagulation. Ann Hematol 2008; 87 451-7.

19. Bottasso B, Mari D, Coppola R, Santoro N, Vaglini M, Mannucci PM Hypercoagulability and hyperfibrinolysis in patients with melanoma. Thromb Res 1996; 81: 345-52.

20. Abe K, Shoji M, Chen J, et al. Regulation of vascular endothelial growth factor production and angiogenesis by the cytoplasmic tail of tissue factor. Proc Natl Acad Sci U S A 1999; 96: 8663-8.

21. Hughes L, Malone C, Chumsri S, Burger AM, McDonnell S. Charac terisation of breast cancer cell lines and establishment of a nove isogenic subclone to study migration, invasion and tumourigenic ity. Clin Exp Metastasis 2008; 25: 549-57.

22. Mielicki WP, Gordon SG. Three-stage chromogenic assay for the analysis of activation properties of factor $X$ by cancer procoagu lant. Blood Coagul Fibrinolysis 1993; 4: 441-6.

23. Mosmann T. Rapid colorimetric assay for cellular growth and survival: application to proliferation and cytotoxicity assays. J Immunol Methods 1983; 65: 55-63.

24. Kaplinska K, Rozalski M, Krajewska U, Mielicki WP. Cancer pro coagulant (CP) analysis in human WM 115 malignant melanoma cells in vitro. Thromb Res 2009; 124: 364-7.

25. Falanga A, Toma S, Marchetti $M$, et al. Effect of all-trans-retinoic acid on the hypercoagulable state of patients with breast cancer. Am J Hematol 2002; 70: 9-15.

26. Chow SK, Chan JY, Fung KP. Inhibition of cell proliferation and the action mechanisms of arsenic trioxide (As203) on human breast cancer cells. J Cell Biochem 2004; 93: 173-87.

27. Falanga A, Consonni R, Marchetti M, Locatelli G, Garattini E, Pas serini CG, Gordon SG, Barbui T. Cancer procoagulant and tissue factor are differently modulated by all-trans-retinoic acid in acute promyelocytic leukemia cells. Blood 1998; 92: 143-51.

28. Falanga A, Consonni R, Marchetti M, Mielicki WP, Rambaldi A, Lanotte M, Gordon SG, Barbui T. Cancer procoagulant in the human promyelocytic cell line NB4 and its modulation by all-trans-retino ic acid. Leukemia 1994; 8: 156-59.

29. Falanga A, lacoviello L, Evangelista V, et al. Loss of blast cell procoagulant activity and improvement of hemostatic variables in patients with acute promyelocytic leukemia administered all-trans-retinoic acid. Blood 1995; 86: 1072-81.

30. Devarajan E, Sahin AA, Chen JS, et al. Down-regulation of caspase 3 in breast cancer: a possible mechanism for chemoresistance. Oncogene 2002; 21: 8843-51.

31. Janicke RU. MCF-7 breast carcinoma cells do not express caspase-3. Breast Cancer Res Treat 2009; 117: 219-21.

32. Liang Y, Yan C, Schor NF. Apoptosis in the absence of caspase 3. Oncogene 2001; 20: 6570-78.

33. Baj G, Arnulfo A, Deaglio S, et al. Arsenic trioxide and breast cancer: analysis of the apoptotic, differentiative and immunomodulatory effects. Breast Cancer Res Treat 2002; 73: 61-73.

34. Lin LM, Li BX, Xiao JB, Lin DH, Yang BF. Synergistic effect of all-trans-retinoic acid and arsenic trioxide on growth inhibition and apoptosis in human hepatoma, breast cancer, and lung cancer cells in vitro. World J Gastroenterol 2005; 11: 5633-7.
35. Gu OL, Li NL, Zhu ZG, Yin HR, Lin YZ. A study on arsenic trioxide inducing in vitro apoptosis of gastric cancer cell lines. World J Gastroenterol 2000; 6: 435-7.

\section{Address for correspondence}

\section{Ewelina Hoffman}

Department of Pharmaceutical Biochemistry

and Molecular Diagnostics,

Medical University of Lodz

Muszyńskiego 1

90-151 Lodz, Poland

e-mail: ewelina.hoffman@gmail.com

Submitted: 5.02.2013

Accepted: 8.11.2013 